\title{
Relation of diagnostic serum amylase levels to aetiology and severity of acute pancreatitis
}

\author{
M Winslet, C Hall, N J M London, J P Neoptolemos
}

\begin{abstract}
The sensitivity of diagnostic serum amylase $(>1000 \mathrm{iu} / \mathrm{l})$ was assessed in 417 patients with acute pancreatitis as a result of gall stonies (258), alcohol (104), or miscellaneous causes (55), of whom $111(27 \%)$ had a clinically severe attack (including 34 deaths). On hospital admission, an amylase value diagnostic of pancreatitis was found in $96.1 \%$ of all mild cases and in $87.4 \%$ of severe cases $(p<0.001)$; at 48 hours these values were $33.3 \%$ and $48.2 \%$ respectively $(p=0.026)$. Diagnostic amylase levels for alcoholic patients were found in $\mathbf{8 6 \%}$ of mild cases on admission and in $76 \%$ of severe cases $(p<0.001$, compared with other groups). The diagnostic levels were also significantly lower at 24 hours for both the alcoholic and miscellaneous groups compared with the gall stone group $(\mathbf{p}<0.001)$. Eight of $27(30 \%)$ patients with a serum amylase activity $<1000 \mathrm{iu} / \mathrm{l}$ had pancreatic necrosis compared with 12 of the remaining $390(3 \cdot 1 \%)$ patients $(p<0.001)$; the mortality was also significantly different $(44 \% v 5.6 \%$ respectively, $\mathrm{p}<0.001)$. These data support the view that more sensitive tests for acute pancreatitis are needed for routine use especially in those whose disease has an alcoholic aetiology.
\end{abstract}

The serum amylase activity rises sharply within the first 24 hours of an attack of acute pancreatitis and then declines steadily to normal levels over the following 5-7 days. ${ }^{12}$ Although a number of abdominal and extra-abdominal conditions can result in a high amylase activity, ${ }^{3}$ in patients with an appropriate clinical picture, the specificity and the sensitivity are well over $90 \%$. ${ }^{45}$ With the generally available Phadebas method (normal range 70-300 iu/l), the level diagnostic of acute pancreatitis is considered to be $>1000-1200,{ }^{156}$ although an MRC study used a level $>2000 \mathrm{iu} /$. $^{7}$ However, any value above the upper limit of normal is sometimes used by authors from Europe $^{8}$ and North America. While it is generally stated that the amylase activity has no prognostic importance, ${ }^{10} 11$ precise details relating this to both aetiology and the severity of the attack are surprisingly lacking.

A number of studies have challenged the primary diagnostic role of serum amylase, and a case has been made for the use of serum lipase instead,,$^{31213}$ as it remains raised for a slightly longer period. ${ }^{14}$ In a study in which computed tomography was used ${ }^{8}$ to assess the pancreas, a normal amylase activity $(<160 \mathrm{iu} / \mathrm{l})$ was seen in $19 \%$ of 352 attacks of acute pancreatitis; ${ }^{8}$ implicitly, a diagnostic level in this study was taken as any value above the upper limit of normal. No difference was found between patients with a normal serum amylase value and the subsequent clinical course. Most patients presented at least two days after the onset of the attack, 34\% had à gall stone aetiology, and $29 \%$ had a clinically severe course. ${ }^{8}$ If the results in this study were applicable to Britain, these would strengthen the case for the routine use of lipase. The value of amylase determination as a diagnostic tool may be influenced by the prevalence of different aetiological factors, the proportion of severe attacks, and the time that patients are usually admitted to hospital after the onset of an attack, and the present study was undertaken to assess these relations in two hospitals from the Midlands region of England.

\section{Patients and methods}

In the 10 year period up to January 1990 , 417 consecutive patients presenting to Leicester Royal Infirmary and Dudley Road Hospital, Birmingham with a clinical diagnosis of acute pancreatitis were personally reviewed by at least one of the authors (Table I). The senior author (JPN) was involved in the management of patients at both hospitals, which was in principal very similar. Patients with pancreatitis as a result of trauma, metastases, carcinoma, cytotoxic therapy, and iatrogenic causes were excluded. The diagnosis was based on a serum amylase activity on admission to hospital of $>1000 \mathrm{iu} / 1$ (normal range 70-300 iu/l; Phadebas method) ${ }^{15}$ in the presence of compatible clinical findings in 385 patients. Lipaemic serum was diluted before determination of serum amylase.$^{16} \mathrm{~A}$ diagnostic level of $>900 \mathrm{iu} / \mathbf{l}$ was also accepted in five patients with associated hyperlipidaemia. ${ }^{3}$ Only 11 of these $390(2 \cdot 8 \%)$ patients had presented $>36$ hours after the onset of the attack.

The remaining 27 patients presented with an amylase level $<1000 \mathrm{iu} / 1$. In 23 patients, the diagnosis was based on a subsequent increase in the serum amylase to $>1000 \mathrm{iu} / \mathrm{l}$, a urinary amylase $>3000 \mathrm{iu} / 1$, or acute pancreatitis confirmed by computed tomography, laparotomy, or necropsy (see Results). The other four patients had an amylase level of 435-904 iu/l without confirmatory tests but with an otherwise typical clinical picture (see Results). Confirmation of the diagnosis in these four cases was not possible because the pancreas could not be visualised by ultrasonography and the patients would not comply with subsequent investigation.

Diagnostic information additional to the amylase determination and clinical findings was provided by computed tomographic examination, which was abnormal in 188 patients. Between 1984 and 1987 computed tomography was used to assess its role in prognostication and 
TABLE I Details of the 417 patients with acute pancreatitis

\begin{tabular}{lllllr}
\hline Aetiology & No(\%) & $\begin{array}{l}\text { Median age } \\
\text { (range) } \\
\text { (years) }\end{array}$ & $\begin{array}{l}\text { Women } \\
(\text { no }(\%))\end{array}$ & $\begin{array}{l}\text { Predicted } \\
\text { severe } \\
(\text { no }(\%))\end{array}$ & $\begin{array}{l}\text { Clinically } \\
\text { severe } \\
(\text { no }(\%))\end{array}$ \\
\hline Gall stones & $258(61 \cdot 9)$ & $63(22-96)$ & $159(61 \cdot 6)$ & $85(34 \cdot 0)$ & $71(27 \cdot 5)$ \\
Alcohol & $104(24 \cdot 9)$ & $41(14-74)$ & $17(16 \cdot 3)$ & $10(9 \cdot 6)$ & $25(24 \cdot 0)$ \\
Miscellaneous & $55(13 \cdot 2)$ & $58(28-87)$ & $26(47 \cdot 3)$ & $17(30 \cdot 9)$ & $15(26 \cdot 3)$ \\
Total & $417(100)$ & $58(14-96)$ & $202(48 \cdot 4)$ & $112(26 \cdot 9)$ & $111(26 \cdot 6)$ \\
\hline
\end{tabular}

TABLE II Number and type of complications according to aetiology

\begin{tabular}{lcclc}
\hline Complication & Gall stones & Alcohol & Miscellaneous & Total \\
\hline Pseudocyst & 22 & 9 & 2 & 33 \\
Pancreatic abscess & 3 & 4 & 2 & 9 \\
Pancreatic necrosis & 11 & 4 & 5 & 20 \\
Duodenal obstruction & 1 & 0 & 0 & 1 \\
Gross ascites & 3 & 2 & 4 & 9 \\
Pleural effusion & 7 & 6 & 1 & 14 \\
Respiratory failure & 18 & 15 & 6 & 79 \\
Cardiac failure & 5 & 1 & 2 & 6 \\
Renal failure & 3 & 3 & 3 & 13 \\
Multisystem failure & 7 & 0 & 1 & 26 \\
Acute cholangitis & 25 & 0 & 0 & 1 \\
Disseminated intravascular coagulation & 1 & 0 & 1 & 2 \\
Cerebrovascular accident & 1 & 1 & 0 & 2 \\
Portal vein thrombosis & 1 & 1 & 0 & $34(8 \cdot 1)$ \\
Pulmonary embolus & 1 & $5(4 \cdot 8)$ & $8(14 \cdot 5)$ & \\
Deaths (no (\%)) & $21(8 \cdot 1)$ & & & \\
\hline
\end{tabular}

to follow the course of pancreatitis. ${ }^{17} 18$ Subsequently, it was used only in assessing severe cases of pancreatitis. Other confirmatory investigations were "Indium leukocyte scanning (abnormal in a further 50 patients) and ultrasound (abnormal in a further 43). In 17 cases, the diagnosis was confirmed only at laparotomy or necropsy.

A modified Glasgow system of staging patients as 'predicted mild' or 'predicted severe' was used. ${ }^{19}$ In addition, patients were classified as 'clinically mild' or 'clinically severe' according to whether local pancreatic or systemic complications developed. The aetiology of the attack was based on pancreaticobiliary imaging - ultrasound, oral cholecystography, endoscopic retrograde cholangiopancreatography (ERCP), and computed tomography - as well as an alcohol and drug history and more specific investigations where appropriate, including determination of fasting lipids. ${ }^{20}$ The serum amylase was also recorded at 24 hours, 48 hours, 72 hours, and 5-7 days after admission.

The pattern of serum amylase changes during the first week of the attack was analysed according to aetiology and predicted severity and actual outcome.

Statistical analysis was undertaken using the $\chi^{2}$ test with Yates's correction as appropriate for categorical variables and the Kruskall-Wallis and two tailed Mann-Whitney U test for continuous variables (Minitab computer Package, University of Pennsylvania). Significance was taken at the level of $p<0.05$.

\section{Results}

The aetiology and severity of the attacks of acute pancreatitis are shown in Table I. The miscellaneous group $(n=55)$ comprised 45 patients with idiopathic pancreatitis; the remainder had attacks caused by hyperlipidaemia $(n=5)$, hyperparathyroidism $(n=3)$, and collagen disorders $(n=2)$. Only five patients predicted to have a mild attack died (1.6\%) compared with 29 patients with a predicted severe attack $(25 \cdot 7 \%$; $\left.\chi^{2}=643, \mathrm{df}=1, \mathrm{p}<0.001\right)$. The differences in mortality in relation to aetiology were not statistically significant $\left(\chi^{2}=4 \cdot 53, \mathrm{df}=2\right.$, $0.5<\mathrm{p}>0.1$ ) (Table II)

Details of patients presenting with an amylase activity $<1000 \mathrm{iu} / 1$ and with confirmatory evidence of acute pancreatitis are shown in Table III; similarly, those without such evidence are presented in Table IV. Sixteen of these 27

TABLE III Details of patients presenting with a serum amylase of $<1000 \mathrm{iu} / \mathrm{l}$ and with confirmatory evidence of acute pancreatitis

\begin{tabular}{|c|c|c|c|c|c|c|c|c|c|c|c|c|}
\hline $\begin{array}{l}\text { Patient } \\
\text { no }\end{array}$ & $\begin{array}{l}\text { Age } \\
\text { (years) }\end{array}$ & Sex & Aetiology & $\begin{array}{l}\text { Predicted } \\
\text { severity }\end{array}$ & $\begin{array}{l}\text { Admission } \\
\text { amylase (iu/l) }\end{array}$ & $\begin{array}{l}\text { Presentation } \\
>36 \text { hours }\end{array}$ & $\begin{array}{l}\text { Maximum } \\
\text { amylase }(i u / l)\end{array}$ & $\begin{array}{l}\text { Urinary } \\
\text { amylase (iu/l) }\end{array}$ & $\begin{array}{l}\text { Pancreatic } \\
\text { complications }\end{array}$ & $C T$ & $\begin{array}{l}\text { Laparo- } \\
\text { tomy }\end{array}$ & $P M$ \\
\hline 1 & 67 & $M$ & GS & $S$ & 202 & - & 1458 (72 hours) & - & Ascites & - & - & - \\
\hline 2 & 69 & $M$ & ID & S & 566 & - & 5584 (24 hours) & - & Necrosis & - & - & + \\
\hline 3 & 61 & M & GS & S & 860 & 3 days & 860 (OA) & - & Necrosis & - & + & + \\
\hline 4 & 49 & M & GS & S & 520 & - & $520(\mathrm{OA})$ & - & Necrosis & - & + & - \\
\hline 5 & 70 & $\mathbf{F}$ & ALC & $S$ & 200 & 3 weeks & 200 (OA) & - & Necrosis & - & + & - \\
\hline 6 & 49 & $\mathrm{~F}$ & GS & M & 390 & - & 390 (OA) & - & Pseudocyst & - & + & - \\
\hline 7 & 54 & M & ALC & $S$ & 412 & 8 days & 412 (OA) & - & Pseudocyst & + & - & - \\
\hline 8 & 66 & $\mathbf{F}$ & ALC & $S$ & 620 & 7 days & 620 (OA) & - & Necrosis & + & + & - \\
\hline 9 & 64 & M & ALC & $\mathbf{M}$ & 576 & 6 days & 710 (24 hours) & 5376 & - & - & - & - \\
\hline 10 & 48 & M & ALC & M & 300 & 7 days & 970 (72 hours) & 7900 & - & - & - & - \\
\hline 11 & 26 & M & ALC & M & 405 & - & $405(\mathrm{OA})$ & 26884 & - & - & - & - \\
\hline 12 & 25 & $M$ & HLIP & $M$ & 588 & 3 days & $588(\mathrm{OA})$ & - & - & - & + & - \\
\hline 13 & 21 & M & ALC & $M$ & 790 & 4 days & $790(\mathrm{OA})$ & 8922 & - & - & - & - \\
\hline 14 & 29 & M & ALC & $S$ & 284 & 3 weeks & $284(\mathrm{OA})$ & - & Abscess & + & + & - \\
\hline 15 & 26 & $M$ & HLIP & $M$ & 708 & 2 weeks & $708(\mathrm{OA})$ & - & - & - & + & - \\
\hline 16 & 60 & $\mathbf{F}$ & ALC & $\mathbf{M}$ & 530 & 9 days & $530(\mathrm{OA})$ & 2820 & Pseudocyst & - & + & - \\
\hline 17 & 50 & $\mathbf{F}$ & ID & S & 638 & 4 days & 3250 (12 days) & - & Necrosis & - & - & - \\
\hline 18 & 22 & M & ALC & $\mathbf{M}$ & 560 & - & 3800 (48 hours) & - & - & - & - & - \\
\hline 19 & 28 & $\mathbf{M}$ & ALC & $\mathbf{M}$ & 998 & - & 1246 (24 hours) & - & - & - & - & - \\
\hline $20^{\star}$ & 22 & M & ALC & $\mathbf{M}$ & 468 & - & 2310 (7 days) & - & - & - & - & - \\
\hline $21 \dagger$ & 22 & M & ALC & $M$ & 940 & - & 5970 (24 hours) & - & - & - & - & - \\
\hline 22 & 64 & $M$ & ALC & $\mathrm{S}$ & 475 & 7 days & 475 (OA) & - & Necrosis & - & + & + \\
\hline 23 & 62 & $\mathbf{F}$ & ALC & $\mathbf{S}$ & 244 & - & 492 (29 days) & - & Necrosis & - & + & + \\
\hline
\end{tabular}

$\mathrm{OA}=\mathrm{On}$ admission; $\mathrm{GS}=$ gall stones; $\mathrm{ID}=$ idiopathic $\mathrm{ALC}=$ alcohol; $\mathrm{HLIP}=$ hyperlipidaemia $\mathrm{CT}=$ computed tomography; $\mathrm{US}=$ ultrasound; $\mathrm{PM}=$ post mortem * US serial examinations confirmed an enlarged oedematous pancreas.

† Indium - leukocyte scan confirmed acute pancreatitis. 
TABLE IV Details of patients presenting with a serum amylase value of $<1000$ iull on admission in whom diagnosis was based hyperamylasemia and clinical picture alone

\begin{tabular}{llllllll}
\hline $\begin{array}{l}\text { Patient } \\
\text { no }\end{array}$ & $\begin{array}{l}\text { Age } \\
\text { (years) }\end{array}$ & Sex & Aetiology & $\begin{array}{l}\text { Predicted } \\
\text { severity }\end{array}$ & $\begin{array}{l}\text { Admission } \\
\text { amylase } \\
\text { (iu/l) }\end{array}$ & $\begin{array}{l}\text { Presentation } \\
\text { >36hours }\end{array}$ & $\begin{array}{l}\text { Maximum } \\
\text { amylase } \\
\text { (iull })\end{array}$ \\
\hline 24 & 32 & M & ALC & M & 904 & 4 days & $904(\mathrm{OA})$ \\
$25^{\star}$ & 21 & M & ALC & M & 435 & 5 days & $435(\mathrm{OA})$ \\
26 & 72 & M & ALC & M & 900 & 3 days & $900(\mathrm{OA})$ \\
$27^{\star}$ & 30 & M & ALC & M & 526 & - & $526(\mathrm{OA})$ \\
\hline
\end{tabular}

$\mathrm{OA}=\mathrm{On}$ admission; $\mathrm{ALC}=$ alcohol; $\mathrm{M}=$ mild

$\star$ Confirmed previous attacks.

TABLE V Serial serum amylase levels according to aetiology and severity

\begin{tabular}{|c|c|c|c|c|c|c|}
\hline \multirow[b]{2}{*}{ Aetiology } & \multirow[b]{2}{*}{ Severity ${ }^{\star}$} & \multicolumn{5}{|c|}{ Serum amylase $($ mean $(95 \% C I)(i u / l))$} \\
\hline & & On admission & 24 hours & 48 hours & 72 hours & 5-7 days \\
\hline \multirow[t]{2}{*}{ Gall stones } & $\begin{array}{l}\mathrm{CM} \\
\mathrm{PM}\end{array}$ & $\begin{array}{l}5271(666) \\
5617(600)\end{array}$ & $\begin{array}{l}2186(455) \\
2599(586)\end{array}$ & $\begin{array}{r}951(257) \\
1399(310)\end{array}$ & $\begin{array}{l}346(67) \\
398(122)\end{array}$ & $\begin{array}{l}308(82) \\
525(198)\end{array}$ \\
\hline & $\begin{array}{l}\text { CS } \\
\text { PS }\end{array}$ & $\begin{array}{l}6129(1874) \\
5960(831)\end{array}$ & $\begin{array}{l}3478(894) \\
3915(1131)\end{array}$ & $\begin{array}{l}1564(703) \\
1505(598)\end{array}$ & $\begin{array}{l}925(486) \\
675(731)\end{array}$ & $\begin{array}{c}1541(941) \\
643(1154)\end{array}$ \\
\hline \multirow[t]{2}{*}{ Alcohol } & $\begin{array}{l}\mathrm{CM} \\
\mathrm{PM}\end{array}$ & $\begin{array}{l}3358(794) \\
3294(594)\end{array}$ & $\begin{array}{l}1092(319) \\
1040(290)\end{array}$ & $\begin{array}{r}645(231) \\
1459(196)\end{array}$ & $\begin{array}{l}422(137) \\
415(143)\end{array}$ & $\begin{array}{l}379(196) \\
440(147)\end{array}$ \\
\hline & $\begin{array}{l}\text { CS } \\
\text { PS }\end{array}$ & $\begin{array}{l}2679(1198) \\
3296(1899)\end{array}$ & $\begin{array}{l}3042(1850) \\
3497(1878)\end{array}$ & $\begin{array}{r}1738(1045) \\
470(2058)\end{array}$ & $\begin{array}{l}559(292) \\
440(188)\end{array}$ & $\begin{array}{l}270(192) \\
346(316)\end{array}$ \\
\hline \multirow[t]{2}{*}{ Miscellaneous } & $\begin{array}{l}\mathrm{CM} \\
\mathrm{PM}\end{array}$ & $\begin{array}{l}5017(2562) \\
5358(3595)\end{array}$ & $\begin{array}{l}2711(3889) \\
2620(6376)\end{array}$ & $\begin{array}{l}1804(3987) \\
1716(5341)\end{array}$ & $\begin{array}{l}594(2550) \\
642(2321)\end{array}$ & $\begin{array}{l}197(161) \\
812(3071)\end{array}$ \\
\hline & $\begin{array}{l}\text { CS } \\
\text { PS }\end{array}$ & $\begin{array}{l}4499(4210) \\
5950(3993)\end{array}$ & $\begin{array}{l}4321(5319) \\
4831(5343)\end{array}$ & $\begin{array}{l}1742(2946) \\
1720(3281)\end{array}$ & $\begin{array}{l}341(563) \\
391(380)\end{array}$ & $\begin{array}{l}421(862) \\
431(686)\end{array}$ \\
\hline \multirow[t]{2}{*}{ All cases } & $\begin{array}{l}\mathrm{CM} \\
\mathrm{PM}\end{array}$ & $\begin{array}{l}3894(1000) \\
4571(1394)\end{array}$ & $\begin{array}{l}2641(631) \\
2178(543)\end{array}$ & $\begin{array}{l}1992(672) \\
1625(447)\end{array}$ & $\begin{array}{l}889(837) \\
525(761)\end{array}$ & $\begin{array}{l}731(670) \\
629(471)\end{array}$ \\
\hline & $\begin{array}{l}\text { CS } \\
\text { PS }\end{array}$ & $\begin{array}{l}3942(1574) \\
5609(2013)\end{array}$ & $\begin{array}{l}2977(1648) \\
3911(1074)\end{array}$ & $\begin{array}{l}1741(1023) \\
1332(877)\end{array}$ & $\begin{array}{r}1203(794) \\
733(531)\end{array}$ & $\begin{array}{l}831(1454) \\
509(983)\end{array}$ \\
\hline
\end{tabular}

^ Clinically mild (CM), severe (CS); predicted mild (PM), severe (PS).

TABLE VI Time course of diagnostic serum amylase levels according to aetiology and clinical severity

\begin{tabular}{|c|c|c|c|c|c|c|}
\hline \multirow[b]{2}{*}{ Aetiology } & \multirow{2}{*}{$\begin{array}{l}\text { Clinical } \\
\text { severity }\end{array}$} & \multicolumn{5}{|c|}{$\%$ with serum amylase $>1000 \mathrm{iu} / \mathrm{l}(\%>300 \mathrm{iu} / \mathrm{l})$} \\
\hline & & On admission & 24 hours & 48 hours & 72 hours & $5-7$ days \\
\hline Gall stones & $\begin{array}{l}\text { Mild } \\
\text { Severe }\end{array}$ & $100(100)$ & $\begin{array}{l}77 \cdot 5(93 \cdot 8) \\
81 \cdot 6(91 \cdot 5)\end{array}$ & $\begin{array}{ll}33 \cdot 7 & (82 \cdot 6) \\
43.9 & (70 \cdot 7)\end{array}$ & $\begin{array}{r}7 \cdot 1(46 \cdot 4) \\
17 \cdot 0(53 \cdot 2)\end{array}$ & $\begin{array}{r}5 \cdot 0(25 \cdot 0) \\
10 \cdot 4(41 \cdot 7)\end{array}$ \\
\hline Alcohol & $\begin{array}{l}\text { Mild } \\
\text { Severe }\end{array}$ & $\begin{array}{l}86.0(100) \\
76.0(96 \cdot 0)\end{array}$ & $\begin{array}{l}37 \cdot 0(88 \cdot 9) \\
80 \cdot 0(100)\end{array}$ & $\begin{array}{ll}26 \cdot 2 & (73 \cdot 8) \\
50 \cdot 0 & (70 \cdot 0)\end{array}$ & $\begin{array}{l}7 \cdot 7(38 \cdot 5) \\
7 \cdot 7(46 \cdot 2)\end{array}$ & $\begin{array}{r}12 \cdot 9(38 \cdot 7) \\
6 \cdot 3(25 \cdot 0)\end{array}$ \\
\hline Miscellaneous & $\begin{array}{l}\text { Mild } \\
\text { Severe }\end{array}$ & $\begin{array}{l}94 \cdot 7(100) \\
86 \cdot 7(100)\end{array}$ & $\begin{array}{c}33 \cdot 3(66 \cdot 7) \\
100(100)\end{array}$ & $\begin{array}{l}36 \cdot 4(72 \cdot 3) \\
50 \cdot 0(100)\end{array}$ & $\begin{array}{c}9 \cdot 1(45 \cdot 5) \\
0(50)\end{array}$ & $\begin{array}{r}9.5(33.3) \\
+2.9(71.4)\end{array}$ \\
\hline All cases & $\begin{array}{l}\text { Mild } \\
\text { Severe }\end{array}$ & $\begin{array}{l}96 \cdot 1(100) \\
87 \cdot 4(98 \cdot 2)\end{array}$ & $\begin{array}{l}56 \cdot 7(78 \cdot 0) \\
82 \cdot 4(94 \cdot 7)\end{array}$ & $\begin{array}{ll}33 \cdot 3 & (80 \cdot 4) \\
48 \cdot 2 & (72 \cdot 2)\end{array}$ & $\begin{array}{r}7 \cdot 3(44 \cdot 5) \\
15 \cdot 0(56 \cdot 7)\end{array}$ & $\begin{array}{r}6.6(27.9) \\
11.9(40.3)\end{array}$ \\
\hline $\begin{array}{l}\text { All cases } \\
\text { Mild } v \text { severe }\end{array}$ & $\begin{array}{l}\chi^{2} \\
\mathrm{p}\end{array}$ & $\begin{array}{l}10.52 \\
<0.001\end{array}$ & $\begin{array}{l}12 \cdot 60 \\
<0 \cdot 001\end{array}$ & $\begin{array}{l}4.97 \\
0.026\end{array}$ & $\begin{array}{l}3 \cdot 85 \\
0 \cdot 05\end{array}$ & $\begin{array}{l}2 \cdot 84 \\
0 \cdot 066\end{array}$ \\
\hline
\end{tabular}

patients (59\%) presented more than 36 hours after the start of the attack. Eight $(30 \%)$ of the patients with an amylase activity $<1000 \mathrm{iu} / \mathrm{l}$ had pancreatic necrosis compared with $12(3 \cdot 1 \%)$ of the remaining 390 patients $\left(\chi^{2}=39 \cdot 0, \mathrm{df}=1\right.$, $\mathrm{p}<0 \cdot 001)$. All four of the patients with pancreatic necrosis caused by alcohol presented with a low amylase value. There were also 12 deaths (44\%) in patients with a low amylase value compared with 22 deaths $(5.6 \%)$ in patients presenting with a diagnostic level $\left(\chi^{2}=50 \cdot 8\right.$, $\mathrm{df}=1, \mathrm{p}<0.001$ )

The actual values of serum amylase in the different groups and in relation to disease severity are shown in Table $\mathrm{V}$. There was no difference overall between mild and severe cases, using prognostic or clinical criteria. Patients in the alcoholic group had lower admission serum amylase values for both mild and severe disease compared with the gall stone group or the miscellaneous group (all $\mathrm{p}<0.05$ at least). Patients with clinically severe disease showed an increase in mean amylase activities for the first 24 hours compared with mild cases $(\mathrm{p}<0 \cdot 05)$. For other aetiologies, irrespective of severity, there was a fall in the level during the first 24 hours (all $\mathrm{p}<0.05$ at least). Patients with clinically severe pancreatitis associated with gall stones, however, had higher values than clinically mild cases at 24 hours to 5-7 days (all $\mathrm{p}<0.05$ ). Similarly, patients with clinically severe gall stone associated pancreatitis had higher amylase values than patients with clinically severe alcohol induced pancreatitis (all $\mathrm{p}<0.05$ ) and those in the miscellaneous group at 72 hours and 5-7 days (all $\mathrm{p}<0.05$ ).

Diagnostic levels of serum amylase are shown in Table VI. There was a lower incidence of diagnostic serum amylase $(>1000$ iu/l $)$ in alcoholic patients on hospital admission $\left(\chi^{2}=323, \mathrm{df}=2, \mathrm{p}<0.001\right)$. At 24 hours after admission, both the alcoholic and miscellaneous groups also had a lower incidence of diagnostic serum amylase level compared with the gall stone group $\left(\chi^{2}=15 \cdot 8, \mathrm{df}=2, \mathrm{p}<0.001\right)$. Patients with clinically mild disease had a significantly higher 
incidence of diagnostic amylase levels on admission to hospital but this was reversed at 24, 48, and 72 hours later and this trend was apparent at one week (Table VI).

\section{Discussion}

In assessing the accuracy of a diagnostic test it is important to compare this with the 'gold standard' diagnostic tool for the disease. In the case of acute pancreatitis, this is histology, but it is impractical for a large study. Since we wished to examine the sensitivity of a diagnostic amylase level (>1000 iu/l), a compatible clinical picture with any raised amylase value was used and/or in conjunction with other confirmatory information if this was less than the diagnostic level. While computed tomography was not used in all our patients, we do not feel that this negates the study. Confirmatory investigations were available in $298(71 \%)$ of the patients; of the remainder only four had an amylase level of $<1000 \mathrm{iu} / \mathrm{l}$ and all had a value that was above the upper limit of normal (Table IV). We showed previously that computed tomography was abnormal in $94 \%$ of patients with a typical clinical picture of acute pancreatitis and an amylase value of $>1000 \mathrm{iu} / \mathrm{l},{ }^{18}$ while Clavien $e t a l^{21}$ reported a sensitivity for computed tomography of $91 \%$ in patients with a compatible clinical and amylase value above the normal level. (Precise specificity figures for computed tomography are not known but it is likely to be close to $100 \%$ ).

On admission to hospital, a diagnostic amylase level was found in $96 \cdot 1 \%$ of patients with clinically mild disease and in $87.4 \%$ of those with severe disease. These percentages would be $100 \%$ and $98 \cdot 2 \%$ if an amylase level $>300 \mathrm{iu} / 1$ were used. On balance such a high sensitivity, given previously reported specificity rates of over $90 \%,{ }^{45}$ suggests that the serum amylase value is an excellent diagnostic test but there were also a number of important diagnostic limitations.

While the rapid fall in the serum amylase activity is well recognised after the start of the attack,,$^{2}$ the loss of diagnostic sensitivity over the first 48 hours was dramatic. Although the mean serum values were well over $1000 \mathrm{iu} / 1$ at 48 hours in all aetiological groups, only $33.3 \%$ of patients with mild disease and $48.2 \%$ of those with severe disease actually achieved this level. If a level $>300 \mathrm{iu} / \mathrm{l}$ were to be used over this period for diagnosis (see Table VI), it would be associated with a lower specificity of $86 \% .{ }^{4}$ For comparison, the sensitivity of lipase above the upper limit is $99 \%$ but the specificity is only $87 \%$ so the gain of using lipase in this way would only be marginal. ${ }^{4}$ Either serum elastase-1 or trypsin assay would seem to offer the greatest diagnostic advantage after the initial 48 hours, ${ }^{12}{ }^{14}$ but there are technical difficulties and with only limited studies the case for their routine use is far from clear cut. ${ }^{3}$

The diagnostic sensitivity of amylase in the group with pancreatitis caused by alcohol was significantly worse than in the other groups on hospital admission and both the alcohol and miscellaneous groups had a lower diagnostic 'pick up' rate at 24 hours (Table VI). It is in these groups, therefore, that the routine application of lipase seems justified. Patients with clinically severe disease also had lower diagnostic levels on hospital admission but this was subsequently reversed. This is so despite the lack of prognostic significance of absolute values of amylase. ${ }^{1011}$

Our study is consistent with that of Gullick, ${ }^{22}$ which suggested that the serum amylase value would be determined by two factors - the direct relation between the amylase level and the degree of pancreatic duct obstruction and the inverse relation with the severity of the disease. Patients with gall stone pancreatitis had significantly higher admission serum amylase levels than alcoholics, as previously reported. ${ }^{23-25}$ Although there was a much steeper decline in amylase levels for gall stone patients compared with the alcohol group as shown by Hiatt et al ${ }^{26}$ gall stone patients with clinically severe attacks tended to maintain higher mean amylase levels compared with other groups, probably due to 'persisting' pancreatic duct obstruction. ${ }^{27}$

Patients with an amylase value $<1000 \mathrm{iu} / 1$ were more liable to have pancreatic necrosis; moreover this was more frequently associated with death. Reference to Tables III and IV indicates that this was not simply due to a delay in presentation. In other studies, this distinction may have been obscured because of reference to mean rather than diagnostic amylase levels or increased delay in presentation, or both. ${ }^{28}$

Patients with lipaemic serum may have artificially low levels of serum amylase, ${ }^{1620}$ but this is not always the case. ${ }^{28}$ This can largely be overcome by diluting the serum ${ }^{16}$ and by accepting a lower diagnostic threshold, as is our policy. The urinary amylase value may be helpful if this is raised but there is no advantage over serum amylase when used routinely. ${ }^{29}$ Repeating the serum amylase determination at 4-6 hours would be helpful but only three of 27 patients with initially low levels in this study achieved diagnostic levels at 24 hours. Maintaining a high index of suspicion is essential since a high proportion of patients are diagnosed only at necropsy. In a series of 126 patients dying of pancreatitis, this occurred in $53(42 \%)$ cases; moreover, only $5(9 \%)$ had had amylase estimations and these were all normal or subdiagnostic. ${ }^{30}$

In conclusion, there is a strong case for the continued use of amylase determinations in patients with suspected gall stone pancreatitis. Given the comparatively lower diagnostic rate for alcoholic patients and those with an obscure aetiology, however, there is a strong case for the routine introduction of more specific assays such as lipase. ${ }^{3031}$ This is contrary to the view we have previously held. In places where there is a high prevalence of alcoholic pancreatitis, this should probably become the diagnostic test of choice. Patients with unexplained severe upper abdominal symptoms and a normal or only marginally raised serum amylase value require computed tomography in order to determine the presence of severe pancreatitis. ${ }^{32}$

We are grateful to clinical colleagues at the Leicester Roya Infirmary and Dudley Road Hospital for allowing us to report on their patients and to the haematology, biochemistry, radiology, and nuclear medicine departments for investigations. We thank Fay Cox for preparing the manuscript. 
Based on an abstract presented to the BSG, Southampton, September 1990 and published in Gut 1990; 31: A1201.

1 Mayer AD, McMahon MJ, Corfield AP, Cooper MJ Williamson RCN, Dickson AP, et al. Controlled clinical tria of peritoneal lavage for the treatment of severe acute pancreatitis. NEngl f Med 1985; 312: 399-404.

2 Buchler $M$, Uhl W, Malfertheiner P. Biochemical staging of acute pancreatitis. In: Beger $\mathrm{H}$, Buchler $\mathrm{M}$, eds. Acute pancreatitis. Berlin: Springer-Verlag, 1987: 143-53.

3 Clavien PA, Burgan S, Moossa AR. Serum enzymes and other laboratory tests in acute pancreatitis. $B r \mathcal{F}$ Surg 1989; 76 : $1234-43$.

4 Steinberg WM, Goldstein SS, Davis ND, Shamma J, Anderson $\mathrm{K}$. Diagnostic assays in acute pancreatitis. Anderson $\mathrm{K}$. Diagnostic assays in acute pancreatitis.

5 McMahon MJ. Diagnostic assessment in acute pancreatitis In: Glazer G, Ranson JHC, eds. Acute pancreatitis. London Bailliere Tindall, 1988: 251-74.

6 Leese T, Holliday M, Heath D, Gough JG, London N, Hall AW, et al. A multicentre prospective trial of low volume fresh frozen plasma therapy in acute pancreatitis. $B r \mathcal{F}$ Surg 1987; 74: 907-11.

7 MRC Multicentre Trial. Death from acute pancreatitis. Lancet 1977; ii: 632-5.

8 Clavien PA, Robert J, Meyer P, Borst F, Hauser H, Herrmann $\mathrm{F}$, et al. Acute pancreatitis and normoamylasemia. Not an $\mathrm{F}$, et al. Acute pancreatitis and normoamylasemia. N
uncommon combination. Ann Surg 1989; 210: 614-20.

9 Spechler SJ, Dalton JW, Robbins AH, Gerzof SG, Stern JS Johnson WL, et al. Prevalence of normal serum amylase levels in patients with acute alcohol pancreatitis. Dig Dis Sci 1983; $28: 865-9$.

10 Ranson JHC. Etiologic and prognostic factors in human acute pancreatitis: a review. Am $\mathcal{F}$ Gastroenterol 1982; 77: 633-8.

11 Blamey SL, Imrie CW, O'Neill J, Gilmour WH, Carter DC. Prognostic factors in acute pancreatitis. Gut 1984; 25 : $1340-6$

12 Kolars JC, Ellis CJ, Levitt MD. Comparison of serum amylase pancreatic isoamylase and lipase in patients with hyperamylasemia. Dig Dis Sci 1984; 29: 289-93.

13 Ventrucci M, Pezzilli R, Gullo L, Plate L, Sprovieri G, Barbara L. Role of serum pancreatic enzyme assays in Barbara $L$. Role of serum pancreatic enzyme assays in diagnosis of pancreatic disease. Dig Dis Sci 1989; 34: 39-45.
Flamion B, Delhaye M, Horanyi Z, Delange A, Demanet H,

4 Flamion B, Delhaye $M$, Horanyi $Z$, Delange $A$, Demanet $H$, Quenon $M, e t$ al. Comparison of elastase-1 with amylase,
lipase and trypsin-like immunoreactivity in the diagnosis of lipase and trypsin-like immunoreactivity in the diagnosis

15 Leska M, Birath K, Brown B. A new and rapid method for th clinical determination of alpha-amylase activities in human serum and urine. Clin Chim Acta 1969; 26: 437-53.

16 Dunne MJ, Shenkin A, Imrie CW. Misleading hyponatraemia in acute pancreatitis with hyperlipidaemia. Lancet 1979; 211.

17 London NJM, Neoptolemos JP, Lavelle J, Bailey I, James D.
Contrast-enhanced abdominal computed tomography scanning and prediction of severity of acute pancreatitis: a prospective study. BrF Surg 1989; 76: 268-72

18 London NJM, Neoptolemos JP, Lavelle J, Bailey I, James D. Serial computed tomography scanning in acute pancreatitis: a prospective study. Gut 1989; 30: 397-403.

19 Neoptolemos JP, Carr-Locke DL, London NJ, Bailey IA, James D, Fossard DP. Controlled trial of urgent endoscopic retrograde cholangiopancreatography and endoscopic sphincterotomy versus conservative treatment for acute pancreatitis due to gallstones. Lancet 1988; ii: 979-83.

20 Miller A, Lees RS, McCluskey MA, Warshaw AL. The natural history and surgical significance of hyperlipidaemic abdominal crisis. Ann Surg 1979; 190: 401-8.

21 Clavien PA Hauser N, Meyer P, Rohner A Value of contrastenhanced computerized tomography in the early diagnosis and prognosis of acute pancreatitis. A prospective study and prognosis of acute pancreatitis. A pros

22 Gullick HD. Relation of the magnitude of blood enzyme elevation to severity of exocrine pancreatic disease. Dig Dis 1973; 18: 375-83.

23 Blamey SL, Osborne DH, Gilmour WH, O'Neill J, Carter DC, Imrie CW. The early identification of patients with gallstone pancreatitis using clinical and biochemical factors only. Ann Surg 1983; 198: 574-8.

24 Mayer AD, McMahon MJ. Biochemical identification of patients with gallstones associated with acute pancreatitis on the day of admission to hospital. Ann Surg 1985; 201: on the

25 Van Gossum A, Seferian V, Rodzynek JJ, Wetiendorff $P$, Cremer M, Delcourt A. Early detection of biliary pancreatitis. Dig Dis Sci 1984; 29: 97-101.

26 Hiatt JR, Calabria RP, Passaro E, Wilson SE. The amylase profile: a discriminant in biliary and pancreatic disease. Am F Surg 1987; 154: 490-2

27 Neoptolemos JP. The theory of 'persisting' common bile duct stones in severe gallstone pancreatitis. Ann R Coll Surg Engl 1989; 71: 326-31.

28 Garden OJ, Dominiczak MH, Shenkin A, Carter DC. The diagnosis of acute pancreatitis in the presence of hyperlipidaemia. Scott Med F 1985; 30: 235-6.

29 Moller-Petersen J, Lamsten J, Klaerke M. Serum and urinary pancreatic enzymes in differential diagnosis of acute panpancreatic enzymes in differential $\mathrm{Palfertheiner} P$, Ditschuneit $\mathrm{H}$, eds. Diagnostic procedures in pancreatic disease. Berlin: Springer-Verlag, procedures in

30 Wilson C, Imrie CW. Deaths from acute pancreatitis: why do we miss the diagnosis so frequently? Int $\mathcal{f}$ Pancreatol $1988 ; 3$ : 273-81.

31 Thomson HJ, Obekpa PO, Smith AN, Brydon WG. Diagnosis of acute pancreatitis: a proposed sequence of biochemical investigations. Scand f Gastroenterol 1987; 22: 719-24.

32 Block S, Maier W, Bittner R, Buchler M, Malfertheiner P, Beger HG. Identification of pancreatic necrosis in severe acute pancreatitis: imaging procedure versus clinical staging. Gut 1986; 27: 1035-42. 